\title{
THE ROLE OF LEADERSHIP IN THE CREATION AND PLANNING OF PACIFICATION POLICE UNITS (UPPS) IN RIO DE JANEIRO
}

\author{
O PAPEL DA LIDERANÇA NA CRIAÇÃO E PLANEJAMENTO \\ DAS UNIDADES DE POLICIA PACIFICADORA \\ (UPPS) NO RIO DE JANEIRO
}

Data de submissão: 08-03-2014 Aceite: 04-10-2015

Joysi Moraes ${ }^{1}$

Sandra R.H. Mariano ${ }^{2}$

Andréa Marinho de Souza Franco ${ }^{3}$

\begin{abstract}
The Pacification Police Units (UPPs), created to recover territories (favelas) dominated by drug traffickers in the city of Rio de Janeiro, came about as a result of the courage and leadership of the head of Public Security Bureau in the State of Rio de Janeiro. The UPPs were created at the initiative of a public administrator and, initially, without the support of the State, and have since become one of the most respected and widely recognized organizations in Brazilian society. Due to the success at dismantling the gangs that controlled the favelas and constituted a parallel state within them, UPPs have become the center of a public policy that has allowed their deployment in other underserved communities. In turn, this has enabled the installation of other public services and facilities such as schools and health centers in the favelas, as well as creating the conditions for the local population to freely come and go. Therefore, the purpose of this article is to analyze the role of leadership in the creation and planning of the UPPs distributed among the favelas of Rio de Janeiro. In preparing this article, emphasis has been given to the use of oral history, a methodology that focuses on the history of the present through the narrative of the subjects who participated in the events. The Situational Strategic Planning and the Freirean perspective were used for analysis. The story of the UPPs was found to revolve around the existence or not of leaders inside and outside the favelas. Even with 37 UPPs already installed in the city of Rio de Janeiro, each one being the result of a different experience with the communities, the role of the leaders in the favelas is still emphasized.
\end{abstract}

Keywords: Pacification Police Units (UPPs), leadership, planning.

\footnotetext{
1 Possui Graduação em Administração pela Universidade Estadual do Ceará (UECE), Mestrado em Administração com ênfase em Gestão de Pessoas pela Universidade Federal do Rio Grande do Norte (UFRN) e Doutorado em Administração com ênfase em Organizações pela Universidade Federal do Rio Grande do Sul (UFRGS). Professora Adjunta da Universidade Federal Fluminense. Coordenadora do Curso de Graduação em Processos Gerenciais - Ênfase em Empreendedorismo. Coordenadora de Pesquisa do Programa de Pós-Graduação em Gestão e Empreendedorismo (PPGE). Rio de Janeiro. Brasil. E-mail: jmoraes@id.uff.br

2 Possui Graduação em Ciências da Computação pela Universidade Federal de Pernambuco, UFPE. Mestrado em Engenharia de Sistemas e Computação Universidade Federal do Rio de Janeiro, UFRJ. Doutorado em Engenharia de Sistemas e Computação pela Universidade Federal do Rio de Janeiro, UFRJ. Professora Associada da Universidade Federal Fluminense (UFF). Chefe do Departamento de Empreendedorismo e Gestão. Coordenadora do Programa de Pós-Graduação em Gestão e Empreendedorismo (PPGE). Niterói. Rio de Janeiro. Brasil. E-mail: sandramariano@id.uff.br

3 Possui Mestrado em Sistemas de Gestão pela Universidade Federal Fluminense (UFF). Diretora de Educação do Sistema FIRJAN. Rio de Janeiro. Brasil. E-mail: josimarscosta@gmail.com
} 


\section{RESUMO}

As Unidades de Polícia Pacificadora (UPPs), criadas para recuperar territórios dominados pelo tráfico na cidade do Rio de Janeiro, nasceram, em grande medida, da ousadia e capacidade de liderança de um gestor público. A partir da iniciativa deste gestor, inicialmente, sem apoio do Estado, foi criada, em 2008, a UPP. Com seu sucesso, ao desarticular quadrilhas que controlavam as favelas, as UPPs foram transformadas em política pública que prevê sua instalação nas comunidades carentes do Rio de Janeiro, viabilizando outras instalações públicas, como escolas e postas de saúde, além de criar condições para que as populações destes locais tenham liberdade de ir e vir. O objetivo deste artigo é tratar do papel da liderança no processo de história da criação e planejamento das UPPs distribuídas nas favelas do Rio de Janeiro. Foi utilizada a história oral, uma metodologia que privilegia a história do tempo presente através da narrativa dos sujeitos que participaram dos acontecimentos. Para análise, foram utilizadas as perspectivas de Paulo Freire e do Planejamento Estratégico Situacional. A história das UPPs gira em torno da existência ou não de líderes dentro e fora das favelas. Mesmo com 37 UPPs já instaladas na cidade do Rio de Janeiro, cada uma é o resultado de uma experiência diferente com as comunidades, o papel dos líderes nas favelas ainda é enfatizada.

Palavras-chave: Unidades de Polícia Pacificadora (UPPs), liderança, planejamento.

\section{INTRODUCTION}

The transfer of Brazil's Capital from Rio de Janeiro to Brasília, in 1960, left a political and economic void in the city of Rio de Janeiro. It was fifteen years before a new role was finally defined for the city of Rio de Janeiro. Several institutional designs were suggested for the former capital city, ranging between two extremes. At one extreme, the symbolic leadership role of the city as the "lighthouse of the nation" was defended, by which its importance and distinction at the national level would be maintained by transforming it into a city-state. At the other extreme, the city of Rio de Janeiro would become the capital city of a state with the same name, in a model that put it at the same level as the other units in the Brazilian Federal Republic, and therefore "a city like any other," that would seek to establish greater regional integration (MOTTA, 2002.)

Thus, in 1975, the 'Marvelous City', as Rio de Janeiro city is often called, became the capital of the new state of Rio de Janeiro, a fusion of the former state of Guanabara and the municipality of Rio de Janeiro. In the early years, "the average annual real growth of the state in the period 19741978 was $7.8 \%$, while, in 1978 domestic income showed an increase of 35\% compared to 1974 " (MOTTA, 2002 p. 29). However, in the 1980s, a period known as the "lost decade", the economic situation in Rio de Janeiro deteriorated due to a convergence of factors. Between 1989 and 1992, its gross domestic product fell by $15 \%$, which was one of the worst rates in Brazil at that time. Between 1991 and 1996, 180,000 manufacturing jobs were lost in the state (LESSA, 2000). This process of economic decline was intensified by the transfer of a large number of companies to other states and by the closure of plants in areas that were becoming increasingly violent.

The Complexo do Alemão, for example, one of the most violent areas of the city, formed by a set of twelve favelas, located in the north of the city, had previously housed several factories that closed as the violence escalated in the city of Rio de Janeiro. The Complexo do Alemão had been the home of the largest of tanning and leather goods industry in the Americas and the second in the largest in the world, employing around 3,000 people. Until the 1980s, the area now covered by the favelas that now make up the Complexo do Alemão, contained the city's main industrial complex. However, by the early 1990s, with the increasing levels of violence, coupled with the economic crisis of that period, it is estimated that about 20,000 jobs were lost in that region alone. With the closure of factories, the area gradually acquired a new setting, with people living in extreme or absolute poverty, and eventually drug trafficking took over the region to the 
extent that the presence of the State became unfeasible (OLIVEIRA, 2010, p. 1,567). A similar pattern of events was repeated in many poor communities in Rio de Janeiro, especially those, better known as favelas, located among the hills that make up the geography of the city.

The gradual deterioration of the political and economic conditions of the city exacerbated urban violence that had its peak in the 1990s, as noted by Leite (2000, p. 73), "over the 1990s, Rio de Janeiro acquired the profile of a violent city. Murders, robberies, assaults, kidnappings, armed confrontations between rival gangs or between them and the police took over the streets in a way that was unheard of in terms of their frequency, magnitude, spatial location and the threat they posed". In this period, there was also an escalation of police violence and the city was dominated by the "metaphor of war". The escalating violence in the city of Rio de Janeiro had a direct impact not only on the safety of the population, but also on the State's economic development. In an almost tautological proposition, there was an even greater growth the rates of violence. Finally, there was a separation between the asphalt (plain) and favela (on the morro (hill)). The 'asphalt' was the home of the middle class, those people perceived by police as citizens who deserve the protection of the State, but who were prisoners in their own homes, threatened by the population in the favelas, where the residents were only entitled to "sub-citizenship" (LEITE, 2003). This is because the criminal gangs did not permit the presence of the State in the favelas, and on the rare occasions that the State intervened, it was in the form of military actions involving heavily armed soldiers in attempts to reduce the fighting between rival gangs for the territorial dominance of the morros (favelas). This was the situation of the city of Rio de Janeiro until 2009.

This situation is gradually being reversed with the putting into practice of a simple idea: to recover for the State those impoverished territories, dominated by armed drug traffickers and militias. This means that the State is making itself present in territories from which it was once barred, mainly through the insertion of Pacification Police Units (UPPs) (FRANCO, 2012). This article is mainly concerned with the creation and planning of these UPPs and especially the role of the leadership in driving the process of creating the UPPs.

\section{The role of leadership in creating the UPPs in Rio de Janeiro from the perspective of Situational Strategic Planning and the Freirean perspective: the theory}

\section{Leadership}

Gillén (2010) claims, that until 1969, sociologists published many more articles on leadership than psychologists and management theorists. But as from the late 1990s, the literature on leadership coming from psychologists and management theorists has increased dramatically and currently articles on leadership authored by sociologists correspond to less than $10 \%$ of those published on the subject, even if we only consider the management theorists.

The most apparent consequence of this phenomenon is that the hegemonic literature on leadership, especially that originating from the mainstream management scholars, points, almost exclusively, in one direction: developing new leaders and training leaders who can get results (GILLÉN, 2010). This is because the leader is considered that person with superhuman and lifesaving qualities who, based on a dependent relationship established with those who are led, is perceived as being critical for the effectiveness of public and private organizational systems (GANZ, 2010; ZUPAN, 2010). As pointed out by Duarte and Pope (2011), the most widely used concept of leadership emphasizes interpersonal influence, the personal and situational ability of a particular individual, i.e., the ability to attract the led, to know how to lead them to achieve and overcome certain goals. 
In Latin America, this literature has been widely publicized and accepted, largely due to a cultural characteristic of Latin American people: the belief that a leader can change the reality of a country or a people. This has been the case in Brazil and Argentina, among others. The poor people of these countries, possibly due to naivety or other reasons, are led to believe that a man, a savior, will be able to solve all the problems (HILGERS, 2012). If such a leader dies, for example, the immediate prospects for solving the problem would be to adopt a faithful follower of the leader-savior as the new leader. That is a new savior who maintains that emotional dependency and hence the belief in the lack of the population's organizational capacity.

In 'Pedagogy of the Oppressed" (1970), Paulo Freire considered the role of such leaders in Latin America and argued that this type of leadership leads the people to be enticed by populism and become mere pawns. Political action with the oppressed, according to Freire (1970) would require acting with them, with the led. Their emotional dependence, the result of the domination in which they find themselves and which creates a false view of the world, can be enjoyed by nobody, but the oppressor (the false leader). Only the leader-oppressor is able to take advantage of this dependence in order to create greater dependency.

This does not mean that there is no place for the leader in the Freirean perspective. It just means that leadership is not the owner but of the popular masses or those who lead temporarily however important, fundamental, indispensable that role may be. The importance of that role does not give such a leader the right to command people blindly toward a goal. If this were so, such a leader would repeat the role of messianic savior, even while attempting to achieve the "salvation" of those he/she leads (FREIRE, 1970).

According to Freire (1987), true leadership has an educational role and is provided within a context of co-intentionality. "Educators and students (the leader and the led), co-intent on reality, find themselves engaged in a task in which they are both subjects in the act, not only of unraveling and to unveiling reality, in fact, but also of recreating it, transforming it" (Freire, 1987, p. 31). From the Freirean perspective, leadership it is not something that is predetermined or subject to training. The leaders discover themselves and emerge during the process of transforming their reality; when they are immersed and conscious of this transformation. It is not like a magic trick, it is necessary to understand the context, be part of it, know the other subjects and want to change what is placed before them.

It is from within this perspective that Carlos Matus $(1991,1993)$ formulated the Situational Strategic Planning (SSP), a method of governmental strategic planning, based on decades of experience in public administration in Latin America, in which leadership is seen not as kind of messianism, but as the result of work an engaged work of the leader. "SSP is a method, a theory of the Public Strategic Planning Office. It is designed to serve the political leaders, the government or the opposition. It is concerned with public problems and is applicable to any organ that is not exclusively market-centered, but is within political, economic and social game "(MATUS, 1996, p. 23). This approach will be used in this article to show how the UPPs were created and planned. As with the leadership approach used by Paulo Freire, Situational Strategic Planning (SSP) is little known or used among mainstream Management. This is because from the SSP perspective, it is not possible to plan the life a certain set or of a community and get predefined results as if all the other subjects involved were paralyzed and remained so until the desired results are achieved. 


\section{Situational Strategic Planning}

The SSP, which takes reality itself as its basis, assumes that it is possible to devise a plan, but that one cannot choose the circumstances in which it will be executed. The SSP takes into account that the participants in a social game do not behave in a predictable manner, in addition, seek to maximize the use of the limited resources they have in order to augment them with each new move. This means that no player can apply deterministic reasoning, such as "If I choose path $X$, the consequence will be $Y$. ." In this case, the position of the leader is that of one among many others in the game and is not given as certain.

According to Matus (1993), if the governor (leader) wants to achieve good results, from the perspective of SSP, he must learn to play the social game. One should also consider and recognize that in SSP, the actor who plans in a social game, is also fighting for space, resources, and influence, like any other, however powerful and influential that actor might be. The governor, therefore, must be prepared for four problems: to know how to explain the reality of the game; know how to outline proposals for action in uncertain conditions; know how to develop strategies to deal with the other players and the circumstances, to calculate what it is possible to do, at every moment, in relation to what can be done to achieve the goals; and to know how to it effectively at an opportune moment, recalculating and completing the plan with additional subordinated improvisation (MATUS, 1991).

Thus, according to Matus (1996), SSP can be summarized in four questions that organize and guide the development of the plan itself and incorporate the four problems mentioned above: How to explain the reality? How to design a plan? How to make the necessary plan feasible? How to act as planned every day?

These are four questions correspond to four basic moments in the development of the methodological approach proposed by Matus (1996): the explanatory, the normative, the strategic and the tactical operational moments. However, it must be made clear that "these moments cannot be seen or treated as steps. They are dynamic, are often repeated, though the content, sphere, place and time may change. Therefore, they should be viewed as a kind of spiral, not as a sequence or something gradual" (ADUM and COELHO, 2007, p. 5). One must remember that reality does not follow a predetermined sequence.

Firstly, the explanatory moment, is to recognize there are several true explanations about the same reality, and especially, that the explanations of opposing players are not the same because each explanation of reality depends on who is explaining that reality. In this case, the leader who is the planner and who is also a player, needs to consider that it will not be possible to solve the problem of the various explanations by stating that one is true and the others are false. But how can one plan in the midst of so many truths?

For Matus (1996), the greater the planner's ability to understand the game and the diverse interests of the players, the greater that planner will be. Therefore, it is in the planner's interest to know the explanations of those who are competing against or cooperating with him/ her because with this knowledge he/she can play better. The planner's explanation becomes more powerful if it considers and, at the same time, differs from those of the other players. In this case, the more the planner understands the other players, the more assertive the planner will be. Understanding the other player, however, does not mean one is obliged to accept his arguments, nor yielding. It means understanding the 'position' of the other players in the game, and especially to understand the 'key' with which he reads his reality and that of the other players.

It is worth noting also that SSP focuses on problems rather than on sectors as does traditional or normative planning. "Reality creates problems, threats and opportunities. The politician 
works with the problems and the people suffer because of the problems. Real problems transverse sectors and there are actors that benefit from or are harmed by them and the actors in the social game deal with problems rather than sectors" (MATUS, 1996, p. 35). Working with problems means: explaining how a problem arises and develops; making plans to attack the causes of the problem by means of operations; analyzing the political feasibility of the plan or checking how to make it feasible; and attacking the problem in practice, conducting planned operations. Hence, for SSP, the first step is to describe the problem with the enumeration of facts showing that the problem really exists.

In the case studied here, the basic problem for the government of Rio de Janeiro was, and continues to be, that in some areas of the city, the territory is under the control of the drug traffickers, which virtually precludes the presence of the State.

The normative moment, in turn, refers to the design of the plan, in the identification of actions that can be implemented to address the problems. For Matus (1993), this is the moment to select the possible operations and actions necessary to achieve the objectives. The plan takes the form of proposals for decisions to be taken based on the perceived initial situation. The normative moment, then, requires an approximate calculation of the results. To do so, it is necessary to recognize the existence of uncertainty and surprises, working with scenarios, contingency plans and other appropriate methods, i.e., recognizing the potential for action of the other actors involved. Thus, SSP takes into account a certain situation-goal that is conditional on a scenario and the possibility of other occurrences because reality is not predictable.

This means that the planner that uses SSP must recognize that there is an asymmetry between the past and the future. The past is over, the future is open to many possibilities and we cannot imagine them all. One can only list the future possibilities, not all of them, and one cannot assign probabilities. How many and what possibilities are included in the list depends on the analyst (planner), his imagination, experience and knowledge of the situation. Nevertheless, however competent the planner, the list will always be incomplete and there is always the risk. Thus, according to Matus (1996, p. 64), for planners who opt for SSP, "the plan cannot be a scientific calculation but is instead based on the concept of the strategically-based gamble. "The plan is a gamble, and for some tamed mentalities, this seems like a lack of systematization". The plan is a gamble because its outcome does not only depend on the plan itself. It also depends on the circumstances that are uncontrollable and impossible to predict.

The strategic moment is the feasibility of the plan is analyzed in order to determine 'what can be done' and 'how to do it', seeking to identify strategies that can be used. For SSP, it is necessary to consider the possible strategies in the light of the behavior of the other actors and the capabilities involved. One must therefore consider the power relations, the political power, the knowledge, organizational skills and the financial resources of the social actors involved. When considering the power relations, the planner distinguishes the part of the plan that can be governed directly by the actor from that part that requires the cooperation of other actors to achieve the desired goals.

This means that, to enable the plan, the planner must know the actors involved, the necessary operations, the strategic means and the time available for the operations to produce the desired or expected effect. The following issues need to be clarified: What operations are unfeasible in the initial situation? With which actors is it possible to work in order to make unfeasible operations feasible? What strategic means can be applied to the operations and actors to create conditions favorable to the future viability of the plan? What is the sequence and in what time is it possible to locate operations and deal with opponents in order to make the process of constructing feasibility more efficient? 
The strategic moment, therefore, includes a feasibility analysis of the plan at three levels: the political feasibility, which deals with cooperation strategies and involves negotiations to agree common paths of action through reciprocal compromises, where one actor gains the adhesion of another to his own position and where conflict serves as a field for the actors to measure the weight of their projects; the economic feasibility, which should determine whether the political, economic and organizational projects are economically feasible; and the institutional-organizational feasibility, which will have to determine whether there is sufficient organizational capacity to sustain the proposed program, if there exists the capacity to improve the institutional organization and if the organization designated to fulfill the plan is feasible and effective (LANA and GOMES, 1996).

The tactical-operational moment, in which the key point is to understand that planning is the result of mediation between knowledge and action, it is the moment to deploy and execute the plan, to mobilize the necessary resources. It is action supported planning, creating a continuous process between the three previous moments and the daily action. As noted by Matus (1996, p. 104), it is concerned with "recalculating the plan and improving it according to the circumstances at the time of action and the operational detail that practice demands." It is at this moment that the plan is realigned and improved according to the circumstances at the time of action and operational detail that practice requires.

In fact, as Adum and Coelho $(2007$, p. 2 ) point out "planning must be understood as a process of learning, correction and learning, that obliges permanent corrections are made to the paths of the defined actions." In other words, the essence of SSP is the ongoing monitoring of the situation and the assessment of the results of the decisions taken and deferred judgments, in order to check whether the results produced are in the line with the expected results.

As can be seen, from the Situational Strategic Planning (SSP) perspective, the leader's role is that of an individual who understands the situation in which he finds himself, i.e. the place where he and the social and actors involved are, and based on an analysis of the situation, ascertains which is action should best be implemented. That means require superhuman ability, but a manager who is aware of the situation at any given time. This leadership is capable of understanding the dynamics of the situation, the interests of the various players, the time to act and, especially, that the same situation does not repeat itself. Therefore, there is no magic formula that allows a leader to deliver the desired results, but instead a leader who is aware of the situation in which he finds himself who seeks to work in partnership and respect the organizational capacity of the other actors.

\section{THE METHOD}

The method of investigation chosen was oral history, which has been described as "A methodology that focuses on the history of the present through the narrative of the subjects and allows the researcher to recover that which is not found in other types of documents" (CAPPELLE, BORGES and MIRANDA, 2010, p. 5). This method allows the researcher to analyze history from the perspective of the actors who participated directly or indirectly in its construction, in this case of the creation and planning of the UPPs.

Oral history "is a research methodology that focuses on interviews with people who participated in, or witnessed, events, situations, as a way of approaching the object of study" (ALBERTI, 1990, p. 2). This methodology should be used in research into contemporary topics, events that occurred in the not too distant past, within the range of living human memory, so one can interview people who participated in the recent past. A particularly important advantage of using 
oral history is the production of reference sources for further studies, since they can be grouped into a collection and made available to researchers.

Oral history, then, is a proposal that considers the experience is lived and remembered differently by each individual, who, when recounting a particular event assigns different patterns of importance or of perception. In this sense, "the deliberate production of the oral history document allows one to recover that which is not found in other types of documents. Finally, it should be noted that the importance of oral testimony may be focused on how it (the event) is remembered" (CAPPELLE, BORGES and MIRANDA, 2010, p. 5).

The greatest potentiality of this type of method is that it rescues the individual as a subject in the historical process. Consequently, it reactivates the conflict between freedom and determinism or between social structure and human action. Individuals, the key elements for the understanding of human life, have often been minimized and marginalized by the scientist who believes that personal documents are too subjective, descriptive and arbitrary to contribute to scientific advancement. Then, world history has been largely written in the language of rationality and absolute accuracy. Oral History, however, favors the voice of the people, not only of the great men, as has occurred. (GOMES and SANTANA, 2010, p. 5).

The process of investigation or the interview, as stated by Bom Meihy (1996), is composed of three steps: pre-interview, which corresponds to the preparation for the meeting with the interviewee; the interview itself, during which the researcher records the interviewees' statements and can intervene with questions when necessary to better understand the details of what is being told, i.e., "how? when? in what way? what for?"; and the post-interview, when the recording is finished and procedures are taken to ensure the safety of the material obtained. This last step includes the process of textualization, in which the speech is adapted to the structure of written text, where the "voice" of the interviewer is suppressed to make the text more enjoyable and fluid at the same time, and where, if the researcher considers it necessary, the interviewee's key words are put in italics throughout the text.

It is noteworthy that all interviews began with key questions, then, each interviewee told his/her story freely, returning to the initial questions only when the interviewee wandered from the topic. The opening questions were about: when the interviewee came into contact with the UPP, when and in what context they had first heard about the UPP, if they had participated in the planning of the UPPs and what their involvement was.

We interviewed 18 people, including presidents of community residents associations, community residents, State Secretaries of Rio de Janeiro and representatives of organizations that supported the creation of the UPPs or are involved in other similar initiatives in the same state. Each interview lasted approximately two hours and, if any further clarification was necessary, the subject was interviewed again. All the interviews were transcribed and read several times in an attempt to identify similarities and differences in each narrative. Although each interviewee deals with the creation of the UPPS from his/her personal point of view, the figure of the leader around which the article was developed is central to each story.

The role of leadership in the creation of the UPPs in Rio de Janeiro from the perspective Situational Strategic Planning and the Freirean perspective: the case Origins and inspirations for the UPPs -2000 to 2007

The first investigations into how the UPPs came into being involved examining academic publications and reports in the mass media. In the main data bases of academic journals 30 arti- 
cles were found that addressed the issue of peacemaking in areas experiencing civil war and/ or in countries ruled by dictators or in very poor regions, such as parts of Africa, for example. In the national and international mass media, reports were found that highlighted the role of the UPPs in the communities of Rio de Janeiro city. In the national mass media experiences with public safety at major events in Rio de Janeiro were reported to have propelled the UPPs were found, especially the Pan American Games, which took place in Rio de Janeiro in 2007. Then, people involved with the safety of the Pan American Games were contacted for research purposes.

The first interviewee was Lieutenant Colonel Claudete Lehmkuhl, a member of the Santa Catarina State Military Police since 1983 and scholar in the field of Public Security Policy and adviser to the Federal Ministry of Justice. According to the Lt-Col Lehmkuhl, regarding security during the Pan American Games, the Ministry of Justice, first contacted the states and requested access to the police databases in order to identify those whose CVs showed knowledge about the area of public safety, particularly any that had worked with public safety involving the citizen as being co-responsible for the safety of the community. Hence, they contacted her.

According to Lt-Col Lehmkuhl, the history of the UPPs began with a survey of requirements for the Pan American Games. The United Nations Development Program (UNDP) and the Federation of Industries of the State of Rio de Janeiro (FIRJAN), carried out a survey of the state of Rio de Janeiro to develop a pilot project in Rio: a public safety project involving community policing.

The story of the UPPs began in the mid-2000s, prior to the Pan American Games in Rio de Janeiro. The idea was to ensure a safe city to host the athletes and the international community. The Pan American Games were marked by an innovative initiative, because the Ministry of Justice (MJ), through the National Secretariat of Public Security (SENASP), was the body responsible for organizing and coordinating the safety of the event. Historically, security of major events was the responsibility of the Armed Forces. What prompted the Presidency of the Republic to choose to make the Ministry of Justice responsible for security was the idea of combining a set of preventive actions to the traditional containment activities of the police, to ensure the safety of the Pan American Games (Lt-Col Lehmkuhl).

To operationalize security in the city of Rio de Janeiro, some programs were created that were only developed in time due to partnerships with organizations in civil society, such as representatives from industry, local communities close to where the Games were to be held and in partnership with government institutions at the federal and state levels. Among the main agencies involved in the implementation of the programs were the Federation of Industries of the State of Rio de Janeiro (FIRJAN), the Social Service of Industries (SESI/RJ), the National Apprenticeship Service (SENAI/RJ) and the Micro and Small Enterprises Support Service (SEBRAE/ RJ). A Letter Agreement was also signed with the Central Union of Favelas (CUFA), with the goal of providing training courses for community leaders. The CUFA, in turn, would mediate between the implementing organizations, SENASP/MJ and the community leaders. The Public Ministry of the State of Rio de Janeiro, the Public Defense Agency of the State of Rio de Janeiro, the Secretary of State for Social Assistance and Human Rights and the Institute of Public Security of Rio de Janeiro also acted as implementing agencies (LEHMKUHL, 2010 p. 72-3).

According to Moema Freire (from the Unit for Social Policies of the United Nations Development Program (UNDP)), the Brazilian government was inspired by a project implemented in Bogotá (Colombia) to establish a new model of public safety. So much so that several multipliers, mainly representatives of Rio de Janeiro police went to see the experiment on-site and participate in training in that country. This concept of Public Safety, Community Police, is greatly inspired by the experience of Bogotá, Medellín. The idea of having a safe city, at the time, was because we did not 
want to repeat the scenario of Rio 92. Then, the tanks in the streets, the frightened people, army soldiers on the slopes of the hills of Rio and the entrances to the city and local events guarded by army tanks. We did not want to repeat this scenario in the Pan American Games. It was necessary to involve the population in public safety. All this, had the support of FIRJAN, from the beginning. Some events were funded by FIRJAN so we could work closer to the population in Rio (Moema Freire).

The participation of FIRJAN is one of the questions that always arises when the subject matter is public safety, "which does the Federation of Industries of the State of Rio de Janeiro have to do with public safety?" And in answer to this question: "in 2006 FIRJAN made a map of development because the situation was desperate. We had no business representation in Rio. The few companies remained had transferred their main offices to São Paulo ... Gerdau CSN ... everyone using bullet-proof cars. Rio was becoming one of the most violent cities in the world. That tension was too much to live effectively. Even today, many of our member companies are still there, the entrepreneur is in Sao Paulo. It was necessary to do something to bring them back (Andrea Marinho, Director of Education FIRJAN in an interview).

The comments from the President of FIRJAN are also quite informative: I think, at first the government did not understand what we wanted to do. But our agenda was also in the public interest. The business class is also part of the population of Rio de Janeiro, it creates jobs, provides resources for the State. It was necessary to do something. And we began to support initiatives that focused on public safety. We put our staff on hand to train, negotiate and finance (Eduardo Eugenio, President of FIRJAN in an interview).

The idea of Matus (1996) of knowing the widest possible range of actors involved in the game was crucial to enlist partnerships in Rio de Janeiro, the government itself, industry and civil society to seek people whose interest, although they might be motivated from different perspectives, would make Rio de Janeiro a safer city to live in, visit and to set up a business.

This operation, which was closed after the Pan American Games, showed the Public Security Bureau of Rio de Janeiro there were new possibilities. But it was also a stopgap measure because the violence after the Games remained the same and, in certain regions, it even became worse.

\section{New leadership in the Public Security Bureau of the State of Rio de Janeiro: planning starts from 2007 - the beginning of the UPPs}

In 2007, the year that the subject (José Mariano Beltrame) highlighted in this article assumed the position of Secretary of the Public Security Bureau of the State of Rio de Janeiro, violence in the city was acquiring new facets with turf wars on the hills of the city between the major drug trafficking gangs in Rio de Janeiro. When I was asked to be Secretary of Public Security, I formed a team and together we started to think about how we could make a difference in Rio de Janeiro and not just spend one term in office. I think the first thing that became clear to everyone was the willingness to do something. It was then that we began to analyze crime rates in the city. They were obviously linked to violence within the areas of hills (in the favelas). In those areas, there was a huge amount of weapons and disputes between different drug trafficking factions and with the militias, prevented the military police from climbing the hills and entering the favelas. In those places, there was a dictatorship in which criminals decided everything as if they were the judiciary. (José Mariano Beltrame, Secretary of Public Security Bureau (PSB/RJ) since January 2007).

When asked about the experiments conducted previously to contain the violence in Rio de Janeiro, the Secretary said that at the time did not know about the experiments carried out for the purpose of hosting the Pan American Games, but had studied what had been done to understand 
what had gone wrong. I think people do not realize that the city of Rio de Janeiro is like a chessboard. The inspiration was not the experience of Medellin - the inspiration was the chessboard. I have the black squares and white squares. My idea was to have it all one color. Not all black or all white, but a mix of the colors. So my team and I had to answer a question: "what do we have to do to mix the colors?" The idea was not to end the favelas, but to end the tyranny that was there inside them, imposed by the weapons of the drug traffickers and the militias. It was a war zone where traffickers and militias determined who could climb the hill and even until what time. In the midst of the city of Rio de Janeiro there were areas where the State did enter and the poorest citizens were held hostage by traffickers and heavily armed militias. (José Mariano Beltrame, PSB/RJ).

Hence, there was a need to retake the territories. First, it was necessary to ensure that these territories were returned to State, that the State had some power in these territories. Any long-lasting action could only occur with the return of the territories dominated by the drug traffickers. The repossession of the spaces under the control of traffickers was necessary the first step to be able to "come to stay". It is with this "come to stay" perspective, that the story of "citizen security" takes a new direction and retraces its path to install community police called Pacification Police Units (UPPs).

To begin with, the Secretary of Public Security Jose Mariano Beltrame, said that it was a struggle to adopt the name the UPP. Using the word "pacification" was a big problem because it might give the impression Rio was at war. Then I said, people, if you are not convinced that these islands of violence are part of the state of Rio de Janeiro, we will not solve this problem. Yes, we're at war. First, you need to recognize that. We can't act as if those areas were not Rio de Janeiro. That is an area at war in Rio de Janeiro. Therefore, you (Governor and other Secretaries of the State of Rio de Janeiro in a meeting) must assimilate that and have to treat this as a war. It is only by recognizing what is happening, by recognizing there is a war in Rio de Janeiro that we can start addressing the problem. Then, point number one is to understand and become aware of the situation. It was also necessary to recognize that the police have problems, that, because of the war, you have this mountain of malignancies, because the police has been trained to engage in war and not to provide a service (José Mariano Beltrame, PSB/RJ).

As already highlighted by Matus (1991), using Situational Strategic Planning (SSP) requires this appreciation of reality, 'face it head on and with no makeup.' The interviews with the Secretary of Security, Mariano Beltrame, show signs of the organizational processes that lead to establishment of the first UPPs. But also make it clear that the communities that would receive the UPPs did not participate in their formulation.

But back to the beginning, the story of the creation and planning of the UPPs.

I say that the UPP is much more about the intention to act, than to build this as a thesis, a plan, because I thought the following ... In four (4) years, I need to show that what we can do, and show that it is possible to show that we know how ... If I were to design it, write it, make a plan, I would not do it in one term in office. Because, after making the plan, I would need another term in office to sell the idea and then another to execute the logistics to put the plan into action. (José Mariano Beltrame, PSB/RJ)

Already in his first comment "the UPP is much more about the intention to act, than to build this as a thesis, a plan" the Secretary signals both urgency in seeking to solve a problem that has been mounting up in the state of Rio de Janeiro, and the will that goes directly to the doing, the "fazimento", in the words of Darcy Ribeiro. An expression which emphasizes that ideas must go hand in hand with action; that also emphasizes action and process, as things may also need "redoing" (Ribeiro, 1997)., 
I think the whole of society in Rio knew what had to be done, that was to enter and stay in those areas. Now, what was planned was the following: how to enter and stay? How will you do that? So that's what we did ... we thought about how we would get in there to stay.

In the first months, we (public security service team) analyzed the city as a whole and saw that it was marked, it was like a chessboard ... You have places in Rio de Janeiro that are like an ordinary, common city, like any other. And you see that within this normal city, you have islands of pure violence, of exclusion ... You have a dictatorship imposed by crime, traffickers or militia and in which the State was not present. (José Mariano Beltrame, PSB/RJ)

The above comment from the Secretary of Public Security reflects what Matus (1996) refers to as the explanatory moment, as the author also points out that working with problems also means: explaining how a problem arises and develops; it is exactly the first step: seek to describe the problem by pointing out the facts that show that the problem really exists.

So first, we mapped the complexes. We took 40 large complexes of favelas. When we talk about Rocinha (one of the largest slums in Latin America), we are not talking about Rocinha. It's Rocinha, Vidigal and Chácara do Céu, there is no point taking Rocinha, if the gangs move over Vidigal. And so on. There's no pint taking Nova Holanda, if you don't occupy the Baixo Sapateiro and all the others favelas that make up the Maré, for example. Tijuca has 17 hills and there you have the three factions. That's why there are the tracer bullets. It is one gang fighting with another. It is not with the police. The police are an ingredient in this fight. They heard about Rocinha all over the the world, why? It was Bem-te-vi (one of the best known drug dealers) who wanted to take I don't know what from I don't know who. Vidigal fought with Rocinha. Business, market. They were there after drug outlets. (José Mariano Beltrame, PSB/RJ)

When Matus (1996) refers to moments in SSP, he is suggesting it is necessary to take one step after another. The reality is much more complex and there is no way of even thinking of planning without knowing the reality, just to be able to start thinking about how to act considering all the actors/players involved.

We had this ... the idea of arriving to stay in a community dominated by drug traffickers ... more or less in place, but I said: "There's no point writing it here. We will spend a year here without giving a definite response". If I were to plan it, write it, I would not do that in a four year term in office; after another four years to convince the Governor. Because, the logistics that I need, It'd take another 4 years, plus another four years to convince another person, another governor to 'buy' my idea. At the time I said "let's get inside a small little place, do a test. I'm not going there, dream about occupying Cidade de Deus, for example. Let's start small." (José Mariano Beltrame, PSB/RJ)

This can be understood as the moment the plan was conceived, identifying the actions which could be implemented to address the problems. Matus (1991) reminds us that efficient planners are not those for whom the details of everyday life are an abstraction, on the contrary: they are immersed in them and are able to find the right moment to act. Thought and action must be united.

New leadership practices in the Public Security Bureau of the State of Rio de Janeiro: the first UPP in 2008

What happened was that, from the moment of the plans conception it was put into action. It happened suddenly. I saw an opportunity because I knew the situation in Morro Santa Marta. In December 2008, there was a large police operation there and the result was that 'Dona Marta' was kind of 'headless'. The crime leaders had been arrested and the main leader had been killed in confrontation with the police. So I said to my staff, "it's now or never. Let's seize the op- 
portunity, if not another gang leader is going assume the role of community leader" We went to Morro Santa Marta, went in there and we occupied a former nursery school that had belonged to the City Hall that the drug traffickers did not let the community use. This also provoked us. We went to the Morro Santa Mart ... But there was that thing ... We had no new police officers to put there... Police trained in a policy of working with the community. They were officers form the Battalion selected by the Commander ... It was an impromptu thing ... And the improvisation work very well. Crime rates fell inside there. I've been there, in Morro Santa Marta, four years ago without a single homicide. (José Mariano Beltrame, PSB/RJ).

Morro Santa Marta, in the neighborhood of Botafogo, in the South Zone of Rio, was the first to receive a Pacification Police Unit, which was inaugurated on December 19, 2008. This is the first experience of the Security Bureau of State Rio de Janeiro with the "community policing' policy, the police officer-public servant. Since then the unit has operated 112 officers who have been trained in a specialized course to learn how to work together with the community. The idea is to reduce overt policing and introduce community policing.

And so the UPP began: there was a problem with a reporter there in Morro Santa Marta. They kidnapped a reporter and it was a militia leader, Nick. He was the leader of the militia who dominated there too. We arrested Nick, so the favela was leaderless. Let's go there.... The team asked, "how way?". I just said "let's go there". We're not going to miss this chance. This is our little project happening here.... Our plan was taking shape.... We still were thinking about how to put this on paper and then we climbed Morro Santa Marta because it was time, and it was time and we couldn't miss the opportunity. There, we went and took the Bangu Battalion. The Battalion entered, was there about 30 days, we managed to form a group .... We started working there without the full structure.

At the beginning it was me and her (the wife of the Secretary of Security who was present during this interview) in Morro Santa Marta. Everything that happened in Santa Marta was because me and Rita (his wife) did it. She even provided welfare assistance, to try and encourage the people to become enthusiastic about the police presence. We managed to place a few doctors there. At first, it was me, the Bangu Battalion and my wife. There was no support from the State because the State did not know it would work. But we saw an opportunity and we could not miss it. That's when I began to speak with other government departments. I said, "folks, this here has to work. The Public Security Bureau came and won back the territory with regard to the safety of the population. The population was no longer held hostage by traffickers and militia. But now, if the rest of the State doesn't appear there to meet social demand, the police will not be able to hold it. Everything will go back to the way it was before. It was necessary to engage with the community. Provide public facilities and services, but without taking away the autonomy of the community. But while the rest of the State was not convinced that this action would work, no-one came."(José Mariano Beltrame, PSB/RJ)

We remember that for Matus (1996), the greater the planner's ability to understand the game and the diverse interests of the players, - the greater the planner's knowledge of the situation and how the players operate, the greater that planner will be. It was only possible to determine that it was the time to take Morro Santa Marta because the social dynamics within that context were known. 
The initiative of new leaders that culminated in new UPP: the planning was being conducted together with the action

Meanwhile, the Commander of Jacarepaguá, where Cidade de Deus is located, just said: "Secretary, I'm going to occupy the favela, Cidade de Deus. Just me".... it was his personal challenge. He went there and occupied it ... occupied it and it worked. It was sort of beyond our team ... He went there, occupied it and it worked. I said: "We can't go back, right?" So I went there and provided support. Soon after, we went to the Morro do Batam in Realengo. It was also an opportunity not to be missed. Just like Morro Santa Marta, the drug traffickers in Batam had also lost their leader and were regrouping. So we went there and didn't leave anymore. Then, after that, things began to fall into place. Then I talked to the staff and said "now is the time to organize some of this on paper. It's time to go back to the little project, to write about what we're doing." (José Mariano Beltrame, PSB/RJ)

The entry of the police in the communities of Dona Marta, Cidade de Deus and Batam are concrete expressions of SSP: a combination of calculation and gambles based on knowledge of the situation, the interplay between the reality and the actors/players involved in the game. As stated by Matus (1996), the plan is a gamble, though for some it may seem like a lack of systematization. Then, it is important to remember that, when considering reality in the elaboration of a plan, the result depends not only on the plan itself, but also on circumstances that are neither controllable nor predictable.

It can be clearly seen that other leaders emerged and they were supported in their efforts by the leader, although the latter had no institutional support from the State. Support, for these initiatives and these leaders both allows the development of Situational Strategic Planning and the emergence of new leaders interested in transforming reality. As pointed out by Gomes and Lírio (2014), in public administration, the involvement and commitment of the leaders and staff they lead is essential for the implementation of the planning.

As Freire (1970), states, it is not possible for the real leader to see the other subjects of the action as mere doers and executors of his decisions. If that were to occur, the other subjects of the action would be denied the opportunity to reflect on their own 'doing'. These subjects would only have the illusion of acting in the role of leadership, i.e., they would be mere performers. For Freire (1970), to the degree that the leader denies true praxis to other subjects of the action, his own leadership is diminished.

Things began to fall into place. We stopped entering certain communities merely because we saw an opportunity ... because no one could deal with it alone. What are the police going to do without the support of the rest of the State? Just enter and leave. Would it repeat the same story as before? We had to go in and the other departments had to come in behind us. After Cidade de Deus, I saw that if there was no strong engagement, our ideas and actions would be unsustainable. Just me and her (the wife of the Secretary of Security) and a few staff members, it would not work. We needed the support of the State, backing from the Government.

So, I went to the Governor and said: "You need to gather the secretaries, city hall and name somebody ... A pivot for all this." I have at least 40 more communities that need this same type of action. Plus the whole city, that has something every day. "You need to appoint a coordinator."Then, the Governor created the Social Pacification Police Unit and named Ricardo Henriques (Coordinator of the UPP Social - a unit that represents the union between the State and the municipality of Rio de Janeiro in meeting the social needs of the population) as coordinator and I began to feel relieved, I ordered people to look for UPP Social. It was then that the government of Rio de Janeiro began to offer support to what, in fact, was an idea that was already underway, 
which had already been implemented in three favelas in Rio de Janeiro, and especially to an idea that was working. It was good, when I feel alone, I just go after the guys and say "Is the State missing here." When the UPP Social arrived, it was the State coming to meet the social demand. It was not just the police. So, nursery schools began to enter, together with school and health centers. Sometimes we even had the installations, the buildings, but they did not work. So, the state arrived and made them work. It is much better than it was. That's how the UPPs started. When the state saw that the initiative was working in the communities, it began to provide support. When you begin to see crime rates drop, there is a good impact in the media... And people jump in. When the Governor saw that actions we had taken were getting results, then he also began to apply pressure to the public security team. He wanted to see the whole city with UPPS. When the baby is cute, everyone wants to be the father, right? So today, if it were up to the State, we would create one UPP per month in the deprived communities in the hills of Rio de Janeiro. But that's not the way, no. you have to go little by little, not just jump. You have to first know the community well and who's operating there, you have to know the dynamics of each community. (José Mariano Beltrame, PSB/RJ)

This is a time of adjustments between the formal and informal, a time to plan based on the results of actions that seem more informal. This could also be seen as a strategic moment, a time to face and analyze the feasibility of the plan, of what is already being done, mainly its political feasibility, to find out 'what more can be done' and 'how to do it', to attempt to identify suitable strategies. According to Vieira, Correia and Lavarda (2013, p. 590), "there are no formal place defined under organizational processes to develop strategies, they are taken under the problem umbrella with collaborative work with the best-found solving practice". To ensure the continuity of the UPPs, it was necessary to review the police force in Rio de Janeiro, revise the curriculum and the type of training offered to the police officers.

Then we realized that we had another problem on our hands. How do we apply community policing when we don't have community police? We only have police officers that make war. The police are not Community Police. The Academy teaches them to make war. So we started a special Community Police training course to prepare officers to work in the UPPs with the communities to be able to meet the needs of the people in the community. So we begin by reformulating the curriculum of the Academy, to form a police officer-server, community policing. Reforming the curriculum of the military police took a year. As difficult as occupying the Complexo do Alemão (one of the most violent areas of the city of Rio de Janeiro, formed by a set of twelve favelas), it was to try to change the mind of the police. (José Mariano Beltrame, PSB/RJ)

This was also a key phase for the continuance of the plan and, at the same time, it is the result of a plan drawn up at the time of the action itself. It was a time to get government support on other fronts, to reinforce an idea with actions to ensure its continuity, changing police training, for example. It was a time to seek the support of other leaders that were emerging, including within the occupied communities. While we sought support from universities to change the curriculum of the Military Police, the leaders of the UPPs that were already working sought support from residents of the communities in which they were located. We already knew that past unsuccessful plans share a common variable: the police didn't work in partnership with the population. In previous experiences, the police merely watched the residents of the communities. Now, we already knew that for the State to arrive and stay it was necessary to work with communities and not for them. (José Mariano Beltrame, PSB/RJ).

In the words of Freire (1970, p. 61) with regards the leader, it is the time when the true leader opens a bold dialog with the masses. His legitimacy is in dialogue with them, not in deception, manipulation or lie. The true leader cannot be afraid of the masses, their expressiveness, 
their effective participation in power. He cannot ignore their knowledge. He cannot fail to provide them with a full account, to talk about his successes, his mistakes, their mistakes, his difficulties.

The comments provided by the Chief Secretary of Staff, Régis Fischer, corroborate those made by the Secretary of Public Security, Jose Mariano Beltrame. When we were in Morro Santa Marta, in the Cidade de Deus and Batam, we thought: "we're doing something different here. But what can we do so that everything can turn out right?". Then, we had the opportunity to provide training for a few police officers in Batam, there with Beltrame. But then came the following drama, when we thought, "how are we going to do what it takes to make it work on a scale that actually reverses the crime rate in Rio de Janeiro?". When we analyzed the issue, we saw that our problem was how to put new police officers in the field because the Police Academy Training Center (CEFAP) lacked the capacity to handle the number of officers that would be needed. Then you begin to find the bottlenecks. We remembered how the CEFAP worked. As incredible as it seems, In the Military Police, teaching the new recruits was seen almost as a punishment for the instructor. For the member of public security services that committed some mistake, did something wrong, the punishment was to go to CEFAP, situated in the West Zone, far away from the city center of Rio de Janeiro. This used to be the way of pulling the bad officer off the street, assigning him to teach at the CEFAP. Usually, the officers teaching the newcomers to the Military Police had issues involving questionable behavior. There you can see the type of training received by the new members of the Military Police. (Régis Fischer, Secretary of the UPP Social).

The key point of the tactical-operational moment, in this case, the implementation of the UPPs, is to understand that planning is the result of mediation between knowledge and action. As Matus (1996, p. 104) points out, it is about "recalculating the plan and improving it according to the circumstances at the time of the action and operational detail that practice requires." It is about remaking the plan in order to put into practice new ideas, reflecting on them and redoing them in a better way.

From the Freirean perspective, this 'remaking' is the defense of praxis, the "theory of doing", It is not to propose a dichotomy in which "doing" is divided into one stage of reflection and another, distant, of action. Action and reflection occur simultaneously. What may happen, when performing critical-reflexive analysis, about reality, about its contradictions, is that one realizes the impossibility of a certain action or that it is inappropriate at that time. But, the very perception that that particular action is not feasible at a given time does not negate the action of those undertaking that reflection. For Paulo Freire, that reflection is also action.

According to the Secretary of Public Security, no two occupation processes are the same and there's never going to a manual that tells me exactly how to do it. Even, the stance of the police is different. So, entering and staying in each of these communities is a different process. There's a different way for each one. You can't repeat the same recipe. It is more or less the same thing, but it's not. Of course, using police officers, with the support of BOPE will, even the army has been employed; in other, we have used the helicopter. The way to get in is different, people are different, welcome us in different ways, the environment is different, and it all counts. That's right, no occupation that is the same as another, and there never will be a manual that tells me how I'm going to do it in Maré and I'll do the same in Vidigal (José Mariano Beltrame, PSB/RJ).

Considering different ways to occupy the community, due to the peculiarities of each one, demonstrates planning according to the situation. For Matus (1996), there is no single way to make a plan because it depends on the characteristics of the reality to which it will be applied. SSP takes into account that a certain situation-objective is also conditional on indeterminate scenarios and occurrences because reality is not predictable. 
I have to admit, at first, we did not design anything, we did not plan it, we didn't even train new leaders, there was no time. We made attempts. A "plan" even a written plan, a plan of the occupation, was only developed when we started thinking about creating a UPP in Rocinha. (José Mariano Beltrame)

Indeed, as highlighted throughout the text on SSP, "planning must be understood as a process of learning-correction and learning, stressing the achievements of permanent corrections to the direction of the defined actions" (ADUM and COELHO, 2007, p. 2). In other words, SSP is, in essence, the constant monitoring of reality and the evaluation of the results of the decisions taken and those considered but not taken in order to verify whether the results produced are consistent with the expected results. This is what has been carried out since the establishment of the first UPP in Morro Santa Marta. Perhaps, not with a formal plan as in traditional or normative planning, but a plan that takes into account the reality and, therefore, the situation of each community and that has proven very effective. Principally, an action that neither denies the role of leadership nor that of the led. In fact, it makes all those involved into a team that includes all the leaders of the communities, the men and women concerned. This means that leaders do not reduce the communities to mere executors of decisions made by the leaders of the Public Security Bureau of the State of Rio de Janeiro.

From the Freirean perspective, leadership is not denied, rather, it is considered essential. What is denied is the absurd division between the praxis of the leader and praxis of the team members, as if the role of the followers was merely to obey the decisions of the leadership. For Freire (1970), this dichotomy exists only as a necessary condition to a situation of domination, in which the leader prescribes and the followers follow the prescriptions. In true leadership, for Freire (1970), there is a unity in which the leadership does not make the led not the object of his possession. Instead, the relationship is a dialogue.

It is necessary to know, furthermore, that leadership is also a teaching-learning relationship. Thus, if the creation of the UPPs occurred due to the recognized initiative of one or a few men, it must be recognized that, currently, they are a model of public security and policing which promotes closer relations between the population and the police, as well as the strengthening of social policy in the communities. By recovering territories occupied for decades by drug traffickers and militias, the UPPs also contribute towards the self organization of the communities. After all, their innovative character is defined by the attempt, at first, to pacify the underprivileged community and this takes place with the return of territories that were or are still dominated by drug traffickers. After the recovering the territories, with more overt policing, the Military Police permanently occupy communities where the State had not been present.

Finally, with the success of the first UPP, installed in the community of Morro Santa Marta in Botafogo, in November 2008, the Governor of Rio de Janeiro, formalized the existence of the “Pacification Police Unit' (UPP) by Decree No. 41,650 of January 21, 2009. Currently, there are already 37 UPPs, in which over 1 million people benefit directly from the units and the plan is to install 50 UPPs by 2016. It should be remembered that, when talking about 50 communities there are, in fact, 200 or maybe 300 . In the Maré favela alone, for example, there are 15 communities and in the Complexo do Alemão, there are 13. 


\section{FINAL REMARKS}

Working with Situational Strategic Planning (SSP) is more or less like taking the first steps to understanding that "men make their own history, but they do not so as they would want; they do not do it under circumstances of their choice but under those with which they are directly confronted"(MARX, 1997, p. 21). We must also add that men also act base on certain perspectives. As Matus $(1991,1996)$ noted, one can imagine, compose a range of possibilities, participate in history, but you cannot define one's destiny. That is the case of the UPPs, they are truly examples of organizations in the making, the success of which depends on the growing participation of the State, society, and especially of the communities where they are installed. Without this active participation, history shows that there is nothing to prevent the war zones from being re-established in Rio de Janeiro.

This is because those who work with the Situational Strategic Planning (SSP), work with the notion of the real system, since it is in these that we live our social practice and this is what we find in our daily experience. It is what Matus (1996) calls the "system of hard uncertainty." It is a model that recognizes that there is asymmetry between the past and the future. The past is over, everything that could have happened has already happened; the future is open to many possibilities and we cannot imagine them all. But we can be creative! We can enumerate future possibilities, but never all of them, of course. And, even with all this uncertainty, it is the world in which we must govern and plan. What was also observed throughout this research, listening to countless narratives, is that the actions taken in order to implement the UPPs originated in the Public Security Bureau, with isolated incursions into communities dominated by drug traffickers, which became institutionally recognized when the society itself began to manifest itself in favor of the UPPs and especially when crime rates began to decline in the regions where the UPPs were installed.

The story of the UPPs was found to revolve around the existence or not of leaders inside and outside the favelas. The first territories were retaken by the State because the leader of drug traffickers in the region was killed or, as stated earlier, it was a moment where the slum was leaderless and people were still reorganizing themselves. It was at this time that the leadership of the Public Security Bureau, perceiving the lack of leadership, entered and retook for the State a territory that had been under the control of traffickers and militia for over twenty years. Even with 37 UPPs already installed in the city of Rio de Janeiro, each one being the result of a different experience with the communities, the role of the leaders in the favelas is still emphasized. They are territorial disputes and each territory that is retaken by the State is a struggle, sometimes armed, with the leaders from the favelas. In the first territories to be retaken, there were frequent violent gun battles and, therefore, the police and the army were used to climb the hills in assaults that surprised the residents of the communities. Today, when such actions are carried out by Public Safety Bureau the people are informed in advance and the most recent operations to recover territories have occurred without a shot being fired. The police officers are better trained in community policing and particularly, the communities in the favelas demand that the government locates UPPs in their regions.

Nevertheless, it is necessary to avoid creating a new situation of dependence in the communities, i.e., new leaders must emerge from within the community and not just replace the leadership of the drug traffickers and militias with the leadership of the police. As noted by Freire (1970), however well-intentioned an action it will only be liberating if it recognizes the ability for self-management of the people and communities. Failure to recognize this ability means creating new situations of dependency. 
Attention needs to given to both the police participation in the life of the communities whose territory has been retaken by the State and the level of real participation on the part of the community in decisions affecting that territory. If this perspective is lost, we will have the mere substitution of one leadership for another, instead of the community deciding its destiny. The proposal of reincorporating territories into the State so that it can provide the services for which it is responsible, such as health and education, should be replaced by a situation in which the representatives of the police become local leaders. The representatives of the police, in the UPPs must be there to ensure that the communities have the right to organize themselves. As highlighted by Freire (1970), real transformations take place in the context of co-intentionality. Community and State co-intentioned to the reality, find themselves engaged in a task in which both are subjects in the action, not only to know reality, but also in the act of recreating it. So that, the community and the State discover themselves to be permanent 'remakers' of reality, in such a way that the presence of the community in search of its liberation, will be more than pseudo-participation, it will be what it should be: engagement.

\section{REFERENCES}

ADUM, José Jamil e COELHO, Gelda Lhamas. O Planejamento Estratégico Situacional - SSP, na gestão pública: o caso da Prefeitura da Cidade de Juiz de Fora. Revista Eletrônica de Economia, n. 9, set. 2007. Acesso em: 17 mar. 2012. Disponível em <http://www.viannajr. edu.br/revista/eco/down.asp?url=doc/ artigo_90001.pdf>.

ALBERTI, Verena. História oral: a experiência do CPDOC. Rio de Janeiro: Contemporânea do Brasil, 1990.

BOM MEIHY, José C. S. (Re)Introduzindo a história oral no Brasil. In: BOM MEIHY, José C. S. (org.). (Re)Introduzindo a história oral no Brasil. São Paulo: Xamã, 1996.

BONDARUK, Roberson Luiz e SOUZA, César Alberto. Polícia comunitária: polícia cidadã para um povo cidadão. Curitiba: Comunicare, 2007.

CAPPELLE, M. C. A.; BORGES, C. L. P. e MIRANDA, A. R. A. Um exemplo do uso da história oral como técnica complementar de SSPquisa em administração. Anais do VI EnEO. Florianópolis (SC): ANPAD, 2010.

DUARTE, Giselle Aparecida Duarte \& PAPA, Adriana Cássia. A utilização da liderança situacional como diferencial estratégico para as organizações contemporâneas. Rev. Adm. UFSM, Santa Maria, v. 4, no 3, set./dez. 2011. p. 364-377. Acesso em: 28 dez. 2014. Disponível em <http://cascavel.ufsm.br/ revistas/ojs-2.2.2/index.php/reaufsm/article/ view/2123/2600 > .

FRANCO, Andréa M. S.. Unidades de Polícia Pacificadora no Rio de Janeiro: história e planejamento estratégico situacional em ação. Dissertação. Rio de Janeiro: Universidade Federal Fluminense, 2012.

FREIRE, Paulo. Pedagogia do oprimido. Rio de Janeiro: Paz e Terra, 1970.

FREIRE, Paulo. Pedagogia da Esperança. Rio de Janeiro: Paz e Terra, 1987.

GANZ, Marshall. Leading change: leadership, organizations and social movements. NOHRIA, Nitin \& KHURANA, Rakesh. Handbook of leadership theory and practice. Boston (Massachusetts): Harvard Business Press, 2010. p. 527-568.

GILLÉN, Mauro F. Classical sociological approaches to the study of leadership. In: NOHRIA, Nitin \& KHURANA, Rakesh. Handbook of leadership theory and practice. Boston (Massachusetts): Harvard Business Press, 2010. p. 223-238. 
GOMES, A. F. \& SANTANA, G. P. A história oral na análise organizacional: a possível e promissora conversa entre a história e a administração. Cadernos EBAPE. BR, v. 8, no 1, Rio de Janeiro, Mar. 2010. p. 1-18. Acesso em: 7 fev. 2014. Disponível em <http://www.scielo. $\mathrm{br} / \mathrm{pdf} / \mathrm{cebape} / \mathrm{v} 8 \mathrm{n} 1 / \mathrm{a} 01 \mathrm{v} 8 \mathrm{n} 1 . \mathrm{pdf}>$.

GOMES, Ricardo Corrêa \& LÍRIO, Viviani Silva. Strategic planning in Brazilian small-scale municipalities: is the balanced scorecard a feasible tool? Rev. Adm. UFSM, Santa Maria, v. 7, no 1, Mar. 2014. p. 8-21. Acesso em: 28 dez. 2014. Disponível em <http://cascavel.ufsm.br/ revistas/ojs-2.2.2/index.php/reaufsm/article/ view/8143/pdf >.

HILGERS, Tina. Clientelism in Everyday Latin American Politics. New York: Palgrave Macmillan, 2012.

LANA, F. C. F.; GOMES, E. L. R.. Reflexões sobre o planejamento em saúde e o processo de reforma sanitária brasileira. Revista LatinoAmericana de Enfermagem, v. 4, n. 1, Ribeirão Preto: EERPUSP, 1996. p. 97-110.

LEITE, Márcia Pereira. Entre o individualismo e a solidariedade: dilemas da política e da cidadania no Rio de Janeiro. Revista Brasileira de Ciências Sociais, v. 15, n. 44, out., 2000.

MATUS, Carlos. O método SSP. In: HUERTAS, Franco. $\mathbf{O}$ método SSP: entrevista com Matus. São Paulo: FUNDAP, 1996.

MATUS, Carlos. Política, planejamento e governo. IPEA: Brasília, 1993. Tomos I e II

MATUS, Carlos. O plano como aposta. São Paulo em perspectiva, v. 5, n. 4, out/dez. 1991. p. 28-42. Acesso em: 18 mar. 2012. Disponível em <http://portal.saude.gov.br/portal/ arquivos/pdf/plano_como_aposta-matus.pdf $>$.

MARX, Karl. 018 brumário e cartas a Kugelmann. Rio de Janeiro: Paz e Terra, 1997.

OLIVEIRA, B. C. S. Reconhecimento, assimetrias e participação popular na gestão compartilhada do Programa de Aceleração do Crescimento (PAC) no Complexo do Alemão/RJ. Anais do III Seminário Nacional e I Seminário Internacional Movimentos Sociais Participação e Democracia. UFSC, Florianópolis, 2010. p. 1565-1579. Acesso em: 06 abr. 2012. Disponível em: <http://www. sociologia.ufsc.br/npms/mspd/a097.pdf>.

RIBEIRO, Darcy. Confissões. Rio de Janeiro: Companhia das Letras, 1997.

VIEIRA, Marcelo P.; CORREIA, Rion B. \& LAVARDA, Rosalia A. Barbosa. Informal strategizing in a public organization. Rev. Adm. UFSM, Santa Maria, v. 6, no 3, Set. 2013. p. 581594. Acesso em: 28 dez. 2014. Disponível em < http://cascavel.ufsm.br/revistas/ojs-2.2.2/ index.php/reaufsm/article/view/5845/pdf >.

ZUPAN, Mark A. An economic perspective on leadership. NOHRIA, Nitin \& KHURANA, Rakesh. Handbook of leadership theory and practice. Boston (Massachusetts): Harvard Business Press, 2010. p. 265-290. 